\title{
Designing a Biogas Plant for an Educational and Scientific Livestock Complex
}

\author{
Irina V. Miroshnichenko ${ }^{1 *}$ and Nadiia V. Nikulina ${ }^{2}$ \\ ${ }^{1}$ Belgorod State Agricultural University named after V. Gorin. \\ ${ }^{2}$ University of Hohenheim. \\ ORCID iD: \\ Irina V. Miroshnichenko0000-0001-9651-218X \\ Nadiia V. Nikulina0000-0002-2385-1794
}

Corresponding Author: Irina

Miroshnichenko; email:

imiroshnichenko_@mail.ru

\section{Dates}

Published 13 January 2022

Publishing services provided by

Knowledge E

(c) Irina V. Miroshnichenko and Nadiia V. Nikulina. This article is distributed under the terms of the Creative Commons

Attribution License, which permits unrestricted use and redistribution provided that the original author and source are credited.

Selection and Peer-review under the responsibility of the 8th Scientific and Practical Conference Conference Committee.

\section{G OPEN ACCESS}

Abstract. To design biogas plants, it is necessary to have accurate data about the properties and biogas productivity of the available substrates. Reference data should not be used because the performance of the same substrate can vary significantly. In this research,chicken, horse, sheep and rabbit manure from one of the farms inthe Belgorod region of Russia were analyzed, and the parameters of a biogas station for the processing of this raw material were calculated.The biogas yield of the substrates was determined using the Hohenheim Biogas Yield Test. It was found that the specific biogas yield from the droppings of broilers, laying hens, rabbits, sheep, and horses, and from corn silage were, respectively, 456, 363, 390, 189, 116 and $618 \mathrm{ml} / \mathrm{g}$ oDM. The methane content in the biogas was 58.00, 58.50, 57.00, 62.00, 65.00 and 53.60\%, respectively. In most cases, the obtained results differed significantly from the data presented in publications of other researchers and reference books. The biogas plant parameter calculations were made according to generally accepted equations, taking into account the characteristics of the studied substrates. Based on the results, it can be concluded that to dispose of the animal excrement of this farm, it is necessary to build a biogas plant with a bioreactor of volume $102.2 \mathrm{~m}^{3}$ and an engine with a power of 12 to $31 \mathrm{~kW}$. The planned output of electric and thermal energy would be 246.19 and $410.27 \mathrm{kWh} /$ day, respectively.

Keywords: Hohenheim Biogas Yield Test, rabbit manure, horse dung, sheep manure, chicken droppings, biogas yield of substrates

\section{Introduction}

In recent years, there has been a rapid development of production in Russia, in particular in the field of agriculture. The consequence of this was a sharp increase in the volume of requiring processing wastes. Usage of the traditional method of manure disposal by applying to the soil is problematic since ecosystems are not able to process the entire volume. Therefore, the introduction of biogas technologies is of increasing interest. The planning and operation of biogas plants should be carried out in cooperation with the enterprises whose wasteshave to be processed. Thus, a practically closed system 
(agroecosystem) is created, the maximum use of resources (substances and energy) is carried out, thewaste generation is minimized.

In Russia, the most practical for biogas production is the treatment of farm animal manure, waste from processing enterprises of the agro-industrial complex, plant residues, etc. The use of this already existing and requiring disposal waste is less costly than the cultivation of renewable plant materials.

Biogas formation is a process that depends on a large number of factors (temperature, the chemical composition of raw materials, intensity of mixing and heating, etc.). Even a slight change in one of the parameters can cause a change, or even a failure, in the system. Biogas productivity is also influenced by the regional factor, including natural and climatic conditions, traditionally cultivated species and breeds of animals, cultivated crops, animal feeding diet, economic characteristics of the region, etc.

In industrial (agricultural) biogas plants, various organic substances are used as substrates to improve economic performance. Designing of a biogas plant begins from the selection and analysis of substrates which have to be processed. In turn, each substrate has a set of properties. Based on these data, the components and parameters of the biogas plant are calculated: reactor volume, engine power, heating and mixing mode of the substrate, volume and multiplicity of substrate supply, substrate mixture, etc. To plan these plants, it is necessary to have accurate data on the potential biogas and methane yield from available substrates - before starting to process a particular substrate on an industrial scale, it must be tested in a laboratory.

At present, in Russia, when designing biogas plants, the characteristics of substrates are used that are given in reference books and manuals of the Directorate for Engineering and Construction in Agriculture (KTBL), etc., according to which plants in Germany are designed $[14,20]$. Thus, the regional aspects of Russian substrates, which may differ significantly from German ones, are not considered. This can adversely affect the operation of biogas plants.

The purpose of this study is to investigate the main indicators of manure biogas yield of various types of agricultural animals and poultry using the example of the educationand research livestock complex Belgorod state agricultural university (SAU) named after V. Gorin (Belgorod SAU), to compare them with the results of other authors studies and, based on the data obtained, to design biogas plant for processing of tested substrates. 


\section{Materials and methods}

The studies were carried out based on the educational and research livestock complex Belgorod SAU, located in the Belgorod region of Russia and the State Institute of Agricultural Engineering and Bioenergy at the University of Hohenheim (Stuttgart, Germany).

The designed biogas station is intended for waste treatment from the livestock complex of the Belgorod State Agrarian University. Research material - fresh manure of farm animals and droppings of chickens kept at this complex. To adjust thebioreactor feeding mixture according to the nutrient ratio, it is planned to introduce additionally corn silage into the feeding regime of the biogas plant.

The initial parameters of raw materials - the mass fraction of dry matter (DM) and organic dry matter (oDM) - were determined according to [30], the biogas yield of substrates -SBY and methane content - by setting the Hohenheim Biogas Yield Test in accordance with [11, 16, 34].

The substrates were preliminarily dried at a temperature of $+58-+60^{\circ} \mathrm{C}$ for 48 hours, ground to a particle size of no more than $1 \mathrm{~mm}$. A $0.4 \mathrm{~g}$ sample was placed in a sealed cylindrical glass reactor flask with a $100 \mathrm{ml}$ piston and $30 \mathrm{~g}$ of inoculum was added to it. The incubation of the substrates was carried out in an oven at a temperature of $+37^{\circ} \mathrm{C}$. The substrates were mixed using a rotor mounted in a heating cabinet. Each substrate was analyzed in three replicates; the samples with inoculum without substrate addition were used as the "zero" variant. Gas sampling was carried out daily, at the beginning of the experiment - up to 4 times a day, then - as gas was formed. The volume of biogas was determined by reading the values on the scale of the flask,the methane percentage was measured by an infrared-spectrometric methane sensor ("Advanced Gasmitter", PronovaAnalysetechnik, Berlin, Germany).To ensure the comparability of the study results, the gas volume was brought to normal conditions according to Equation 1.

$$
\mathrm{V}_{0}=\left(\mathrm{P}^{*} \mathrm{~V}^{*} \mathrm{~T}_{0}\right) /\left(\mathrm{T}^{*} \mathrm{P}_{0}\right),(1)
$$

where:

$\mathrm{V}_{0}$ - dry gas volume under normal conditions, $\mathrm{ml}$,

$\mathrm{V}$ - registered gas volume, $\mathrm{ml}$,

$P$ - gas pressure at the time of measurement, mbar,

$P_{0}$ - atmospheric pressure at normal conditions; $P_{0}=1013$ mbar,

$\mathrm{T}_{0}$-air temperature at normal conditions; $\mathrm{T}_{0}=273 \mathrm{~K}$, 
TABLE 1: Content of DM and oDM in the original substrates

Substrates
Broilerchickensdroppings
Litter of laying hens
Rabbit manure
Sheepmanure
Horsedung
Cornsilage

Massfractionof DM, \%
$58.10 \pm 0.002$
$43.80 \pm 0.004$
$25.80 \pm 0.009$
$44.10 \pm 0.007$
$25.80 \pm 0.003$
$23.53 \pm 0.022$

Mass fraction of oDM, \%
of DM
$92.20 \pm 0.001$
$76.35 \pm 0.002$
$91.00 \pm 0.004$
$86.60 \pm 0.003$
$89.70 \pm 0.002$
$93.39 \pm 0.015$

$\mathrm{T}$ - biogas temperature, $\mathrm{K}$.

The results were processed by the method of variation statistics using Microsoft Excel.

\section{Results and discussion}

\subsection{Investigation of biogas yield of substrates}

The mechanical and chemical composition of animal excrement depends on the type, age, the direction of productivity, diet, a system of keeping animals and poultry, temperature and humidity conditions in a room, the probability of feed particles entering the excrement mass. The biogas yield of substrates is influenced by their chemical composition - the content of substances that can decompose in the of a biogas plant reactor. The mass fraction of DM, and in particular of oDM, is fundamental for calculations when designing a biogas plant. The quantity and composition of the resulting biogas largely depend on this indicator. The DM content of the substrate influences the rheological properties of the bioreactor content. The mass fraction DM and oDM in the analyzed substrates are shown in Table 1.

In publications $[14,20]$ from which data are taken as the basis for the designing of biogas plants in Russia, in the section on substrate characteristics, manure with a DM of $32.00 \%$, oDM $-63.00-80.00 \%$ is given. In the current experiment, the droppings of both laying hens and broiler chickens contained less moisture. This is most likely due to the technology of droppings removal at the educational and research poultry farm of Belgorod SAU. From cages where the laying hens are kept, it enters a manure belt, then is removed to a cross conveyor and then tomanure storage. The cross conveyor is cleaned out from droppings once a day. Thus, the excrement has time to dry out a little - this is also facilitated by the intensive air exchange in the area where the birds are kept. Broiler chickens of the educational and research poultry farm are kept on the floor on deep non-replaceable bedding, the droppings along with the bedding are removed 
when the house is empty at the end of poultry growing - therefore it also dries up. Broiler chicken droppings in the experiment contained on $12.2 \%$ more oDM than given in the manual [20], laying hens droppings were only on 3.65\% poorer in oDM than the maximum value indicated in [20].

In research of Miach et al., DM in chicken droppingswithout litter was 22.5\%, and oDM - 66.72\% [24]. In works of other authors, chicken droppings with DM of 78.82, $76.00,49.62,6.80$ and $3.00 \%$ was used, suggesting that in most cases the authors used either dried or liquid litter. The oDM in this material was $61.54,82.48,55.00$ and $60.00 \%$, respectively $[3,6,10,23,33]$. And in experiments of Böjt et al,adried aqueous solution of chicken droppings was used [4]. The authors do not indicate from birds of which productivity direction the material was obtained.

Thus, data on DM and oDM in chicken droppings vary considerably. In general, the litter of laying hens in the current experiment occupies an intermediate position in terms of dry matter content, and in terms of the mass fraction of organic dry matter exceeds the values obtained by other authors, exceptDalkılıç et al. Broiler chicken droppings in this experiment also occupy an intermediate position in term of DM content andin term of oDMit is much richer than the droppings studied by other authors $[3,4,6,10,23,24$, 33].

In studies carried out at the University of Kiel (Germany), DM in rabbit manure was $50.00 \%$ [5], a similar value is given by Djeukoua et al. - 53.30\% [12]. Cu et al.studied rabbit manure with DM of $32.66 \%$, which is much closer to thereceived results, but oDM in this substrate was only 39.49\% [7]. The oDMof rabbit manure in current studies was the highest; in the works of Djeukoua et al.andPeiretti et al.this indicator was respectively 83.30 and $89.63 \%[12,29]$.

In studies of various authors, the DM in sheep manure ranges from 22.27 to $25.39 \%$, the oDM - from 58.42 to $84.57 \%$ [1, 7, 21]. In this experiment, sheep manure was richer in dry matter and organic dry matter.

The DM in horse dung in different studies varies significantly - from 2.70 to $60 \%$, which is largely due to its mechanical composition (without bedding, with bedding of different types, diluted manure); the oDM in the same works ranged from 64.07 to $91.28 \%[2,25,26,32]$. In the currentstudy, the value of both indicators is closer to the data obtained by Soares Pereira Lopes et al. and Mönch-Tegeder et al.[25, 32]. If to compare the received data with those given in [14], then horse dung from the educational and research livestock complex is on $2.20 \%$ poorer in DM and on $14.70 \%$ richer in oDM. 
TABLE 2: Biogas productivity of substrates

\begin{tabular}{l|l|l|l}
\hline Substrates & SBY, $\mathrm{ml} / \mathrm{g}$ oDM & SMY, ml/g oDM & Methanecontent, \% \\
\hline Broiler chickendroppings & $456.00 \pm 0.004$ & $264.00 \pm 0.001$ & 58.00 \\
\hline Litter of laying hens & $363.00 \pm 0.006$ & $212.00 \pm 0.003$ & 58.50 \\
\hline Rabbit manure & $390.00 \pm 0.004$ & $222.00 \pm 0.003$ & 57.00 \\
\hline Sheepmanure & $189.00 \pm 0.007$ & $117.00 \pm 0.002$ & 62.00 \\
\hline Horsedung & $116.00 \pm 0.007$ & $75.00 \pm 0.004$ & 65.00 \\
\hline Cornsilage & $618.00 \pm 0.181$ & $331.00 \pm 0.009$ & 53.60
\end{tabular}

The DM in corn silage in the works of different researchers ranged from 31.74 to $37.00 \%$, which is on average $10.38 \%$ higher than the value in thisstudy. The content of oDM ranges from 95.00 to $96.80 \%$, the difference with the received data is not so great and amounts to $1.92 \%[8,17-19,31]$.

The most informative indicator of biogas yield of substrates is the specific biogas yield (SBY) and specific methane yield (SMY), since the DM and oDM content, for example, in the manure of one animal species can vary - which was also noted in the currentstudy. Therefore, SBY and SMY make it possible to compare the results with the data of other experiments.

The SBYfrom chicken droppings in the experiments is significantly lower than the data obtained by most authors. Thus, in the studies of Miach et al.SBY from chicken droppings with litter was $263.00 \mathrm{ml} / \mathrm{g}$ oDM, and in the studies ofAlfa et al. - 940.00 $\mathrm{ml} / \mathrm{g}$ oDM; the concentration of methane was 71.00 and $61.71 \%$, respectively [3, 24]. In the experiment of Dalkilic et al.whentreating substrates in a single-phase system, this indicator ranged from 459.00 to $517.00 \mathrm{ml} / \mathrm{g}$ oDM, in a two-phase system - from 356.00 to $386.00 \mathrm{ml} / \mathrm{g}$ ODM [10]. When treating manure in a semi-continuous mode, SBY was $554.00 \mathrm{ml} / \mathrm{g}$ oDM with methane concentration of $74 \%$ (i.e., SMY is $410.00 \mathrm{ml} / \mathrm{g}$ oDM) [9]. In bioreactors with recirculation of content at manure and inoculum ratio of 1:3, SBY was $183.0 \mathrm{ml} / \mathrm{g}$ oDM, SMY - $74.00 \mathrm{ml} / \mathrm{g}$ oDM [23].Indeveloped by Gangagni Rao et al. multistage high-speed fermentation mode, SMY equals to $160.00 \mathrm{ml} / \mathrm{g}$ oDM was noted [15]. The SBY from the dried solution of chicken droppings was $209.50 \mathrm{ml} / \mathrm{g}$ oDM [4]. In the studies of Dornelas et al.theSBY was much lower and amounted in different variants from 18.00 to $43.00 \mathrm{ml} / \mathrm{g}$ oDM [13]. Thus, SBY from chicken droppings ranges from 18.00 to $940.00 \mathrm{ml} / \mathrm{g}$ oDM. The data obtained on the SBY corresponds to the average values and are close to the results ofDalkilic et al. $[9,10]$, and in terms of methane content lower than in the works of the above-mentionedauthors.

Data on biogas yield of rabbits are rare in the world literature - this is probably due to the relatively low prevalence of this branch of animal husbandry. In the work of Djeukoua 
et al., the SBY from rabbit manure was $63.66 \mathrm{ml} / \mathrm{g}$ oDM, methane content - 50\% (i.e., SMY - $31.83 \mathrm{ml} / \mathrm{g}$ OCB); in Cu et al. SMY was $172.00 \mathrm{ml} / \mathrm{g}$ oDM [7, 12]. These values are much lower than those obtained in the current experiment. Mahadevaswamy et al. mentioneda very high SBY - up to $24.00 \mathrm{~m}^{3} / \mathrm{kg}$ DM; the authors do not give the content of organic dry matter in the substrate, which makes it difficult to compare the results [22]. Teniza et al. recordeda relatively low SBY of rabbit manure - $38.30 \mathrm{ml} / \mathrm{g}$ oDM; however, it should be noted that in that case, the substrate mixture consisted of $90 \%$ rabbit manure and $10 \%$ goat manure and fermentation was carried out at a temperature of $+25^{\circ} \mathrm{C}$ [34]. In studies carried out at the University of Kiel, the methane content in biogas from rabbit manure reached $64 \%$ [5].

Based on the literature data, SMY from sheep manure ranges from 4.32 to 150.55 $\mathrm{ml} / \mathrm{g}$ oDM; the methane content in biogas ranges from 53.30 to $57.00 \%[1,7,21,27,28]$. In the current experiments, the methane content in biogas is on $5 \%$ higher than the maximum value given in the literature; theSMY is relatively high, but lower than in the work of Cu et al. [7].

The biogas yield of horse dung in thecurrentstudy is lower than in the works of other authors. In the studies of Mönch-Tegeder et al., the SMY from horse dung, as well in combinations with different types of bedding, amounted to $151.00-191.00 \mathrm{ml} / \mathrm{g}$ oDM [25]. Aghayev et al.indicatedthe SBYof $339.00-381.00 \mathrm{ml} / \mathrm{g}$ oDM, and the SMY of $203.00-247.00 \mathrm{ml} / \mathrm{g}$ oDM, the methane content in different variants was 60.00 $65.00 \%$, which is similar to the received data [2]. Methane content in the studies of Mukumba et al.amounted to $51.00 \%$ [26]. The SMY in the current experiment is 2.2 times lower than that given in [14].

The biogas yield of corn silage in the current experiments is quite high and corresponds to the intermediate value among those given in literature sources, including [14, 20]. According to various authors, the SBY from corn silage ranges from 510.57 to 655.00 $\mathrm{ml} / \mathrm{g}$ ODM, the SMY ranges from 272.62 to $381.00 \mathrm{ml} / \mathrm{g}$ oDM and the concentration of methane in biogas ranges from 48,24 to $53.4 \%$ [8, 17 - 19, 31].

Analysis of the chemical composition and biogas yield of substrates once again shows that the data can vary significantly, therefore, the substrates must be tested before treatment in a biogas plant.

\subsection{Calculation of a biogas station parameters}

The total amount of excrement and potential biogas and methane yield per day were calculated based on the data about the number of animals, the daily yield of manure 
TABLE 3: Daily yield of substrates and the amount of energy and fertilizer received

\begin{tabular}{l|l}
$\begin{array}{l}\text { Type } \\
\text { ofanimal/ } \\
\text { bird }\end{array}$ & $\begin{array}{l}\text { Livestock, } \\
\text { head }\end{array}$ \\
$\begin{array}{l}\text { Broiler } \\
\text { chickens }\end{array}$ & 2000 \\
Laying hens & 1500 \\
Rabbit & 250 \\
Sheep & 14 \\
Horse & 11 \\
Cornsilage & \\
Total &
\end{tabular}
Total

\begin{tabular}{l|l}
$\begin{array}{l}\text { Excrement } \\
\text { putfrom } 1 \text { head- } \\
\text { per day, } \mathrm{kg}\end{array}$ & $\begin{array}{l}\text { Total yield } \\
\text { substrates, } \\
\mathrm{kg} / \text { day }\end{array}$ \\
\hline 0.15 & 300 \\
\hline 0.13 & 195 \\
0.2 & 50 \\
\hline 3 & 42 \\
\hline 20 & 220 \\
& 242.1 \\
& 1049.10 \\
\hline
\end{tabular}

\begin{tabular}{l|l|l|}
$\begin{array}{l}\text { Methane } \\
\text { yield, } \\
\mathrm{m}^{3} / \text { day }\end{array}$ & $\begin{array}{l}\text { Degree } \\
\text { decom- } \\
\text { ossition } \\
\text { ofsubstrates } \\
\text { oDM, \% }\end{array}$ & $\begin{array}{c}\text { Fertilizeryield, } \\
\mathrm{kg} / \mathrm{day}\end{array}$ \\
\hline 42.50 & 49.10 & 0.22 \\
\hline 13.85 & 45.00 & 0.17 \\
\hline 2.61 & 49.10 & 0.04 \\
\hline 1.88 & 22.60 & 0.04 \\
\hline 3.84 & 13.50 & 0.21 \\
\hline 17.62 & 70.00 & 0.20 \\
\hline 82.30 & & 0.89 \\
\hline
\end{tabular}

and droppings from one head and the obtained data on the biogas yield of substrates (Table 3). It is planned to use corn silage in the amount of $30 \%$ of the total mass of substrates. The digestate after fermentation are planned to be used in the future as fertilizer in crop production.

Thus, the mass of the loaded substrates will be $1049.10 \mathrm{~kg} /$ day.

The bioreactor volume can be calculated in two ways: based on the hydraulic retention time of the substrates in the bioreactor (equation 2) and considering the reactor organic loading rate(equation 3 ).

$$
\mathrm{V}_{R}=\mathrm{FM}_{d} / 1000 \times \mathrm{HRT}(2) \text {, }
$$

where $\mathrm{V}_{R}$ - bioreactor volume, $\mathrm{m}^{3}$

$\mathrm{FM}_{d}$ - yield of substrates in natural mass per day, $\mathrm{kg}$

HRT - hydraulicretentiontime, $d$

$$
\mathrm{oLR}=\mathrm{ODM}_{d} / \mathrm{B}_{R}(3)
$$

where $\mathrm{V}_{R}$ - bioreactor volume, $\mathrm{m}^{3}$

$\mathrm{oDM}_{d}$ - yield of organic dry matter of substrates per day, $\mathrm{kg}$

oLR - organic loading rate, $\mathrm{kgoDM} / \mathrm{m}^{3}$

In the first case, with HRT of substrates in the reactor for 50 days, the volume of the reactor will be $52.5 \mathrm{~m}^{3}$. With oLR of $3.5 \mathrm{~kg}$ oDM $/ \mathrm{m}^{3}$, this parameter will be $102.2 \mathrm{~m}^{3}$.

Based on the results of calculations, a higher value is taken - thus, the bioreactor volume will be $102.2 \mathrm{~m}^{3}$.

The choice of engine power depends on the planned volume of methane conversion, engine efficiency (COP), as well as on the duration of its operation (Table 4). At the same time, it is considered that when $1 \mathrm{~m}^{3}$ of methane is burned, $9.971 \mathrm{kWh}$ of energy is obtained. 
TABLE 4: Parameters of combined heat and power plant (CHP)

Parameters

Planned volume of methane conversion, $\mathrm{m}^{3} / \mathrm{day}$

Total energy output, $\mathrm{kW}^{*} \mathrm{~h} / \mathrm{day}$

Electric energy output, considering 30\% efficiency, kW*h/day

Heat energy output, kW*h/day

Duration of engine operation, h/day

Installed engine power, kW (per day)

\begin{tabular}{|c|c|c|}
\hline \multicolumn{3}{|c|}{ Values } \\
\hline \multicolumn{3}{|c|}{82.30} \\
\hline \multicolumn{3}{|c|}{820.63} \\
\hline \multicolumn{3}{|c|}{246.19} \\
\hline \multicolumn{3}{|c|}{410.27} \\
\hline 8 & 12 & 21 \\
\hline 30.77 & 20.51 & 11.72 \\
\hline
\end{tabular}

Thus, when designing the biogas plant, three options for engine power are possible. To select a specific model with the best combination of price, power and quality, it is necessary to study the existing range.

\section{Conclusion}

The conducted experiments and literature analysis of other authors works confirm that the composition of substrates and their biogas yield depends, among other things, on their place of origin. It was found that substrates of animal origin obtained from the educational and research livestock complex of Belgorod SAU differ significantly from similar substrates from other regions. Therefore, an analysis of their biogas yield and chemical composition is necessary when designing a biogas plant for a given farm.

In the given experiments, chicken droppings in terms of DM content occupy an intermediate position among the data given in most literature sources, and in terms of oDM exceeds these values, including reference books, which are currently used to design biogas stations in Russia (broiler droppings exceed the maximum value on $12.2 \%$ ). Despite this, the methane content in biogas from poultry droppings from Belgorod State Agrarian University is lower than in the works of most authors.

The DM and oDM in the manure of rabbits and sheep in the current study and their biogas yield were higher than in the works of other authors.

The horse dung of the educational and research farm of the Belgorod State Agrarian University was on $2.20 \%$ poorer in DM and on $14.70 \%$ richer in oDM, and the SMY from it was 2.2 times lower than the data from reference books.

Analysis of the chemical composition of the studied corn silage did not reveal significant differences. Its biogas yield is quite high and corresponds to the intermediate value of the data given in literature sources, including reference books and manuals. The use of corn silage for energy production in Russia is not economically feasible and 
there are other raw materials that are waste products of crop production. Therefore, in the future, it is planned to test other plant substrates for use as an alternative to corn silage.

The calculation of the biogas station parameters for the educational and research livestock complex of the Belgorod State Agrarian University was made according to generally accepted equations, considering the characteristics of the available local substrates. So, for the treatment of excrement from 3,500 chickens, 250 rabbits, 14 sheep and 11 horses, it is necessary to build a biogas plant with a bioreactor ofthe volume of $102.2 \mathrm{~m}^{3}$ and an engine with a power of 12 to $31 \mathrm{~kW}$. The planned output of electric and thermal energy is 246.19 and $410.27 \mathrm{kWh} /$ day, respectively.

\section{Acknowledgments}

The reported study was funded by RFBR according to the research project № 18-47310008 p_a.

For assistance in conducting research, the authors express gratitude to the staff of the State Institute of Agricultural Engineering and Bioenergy at the University of Hohenheim (Germany).

\section{References}

[1] AchinasS, Li Y., Achinas V., Euverink G. Influence of sheep manure addition on biogas potential and methanogenic communities during cow dung digestion under mesophilic conditions. Sustainable Environment Research. 2018;28(5). 240-246

[2] Agayev E,Ugurlu A. Biogas production from co-digestion of horse manure and waste sewage sludge. NSTI-Nanotech. 2011;3. 657-660

[3] Alfa IM, Dahunsi SO, lorhemen OT, Okafor CC, Ajayi SA.Comparative evaluation of biogas production from poultry droppings, cow dung and lemongrass. Bioresource Technology. 2014;157. 270-277

[4] BöjtT, Kovács KL, Kakuk B, Wirth R, Rákhely G, Bagi Z Pretreatment of poultry manure for efficient biogas production as monosubstrate or co-fermentation with maize silage and corn stover. Anaerobe. 2017;46. 138-145

[5] BundesUmweltWettbewerb. IPN - Leibniz-Institut für die Pädagogik der Naturwissenschaften und Mathematik. 2011 November 12. Available from:http://www.buw.unikiel.de/wp-content/uploads/2011/11/hp2_2011.pdf 
[6] Carlini M, Castellucci S,Moneti M. Biogas production from poultry manure and cheese whey wastewater under mesophilic conditions in batch reactor. Energy Procedia. 2015;82, 811-818 https://doi.org/10.1016/j.egypro.2015.11.817

[7] Cu TT, Nguyen TX, Triolo JM et al Biogas production from vietnamese animal manure, plant residues and organic waste: Influence of biomass composition on methane yield. Asian Australasian Journal of Animal Sciences 2015;28(2). 280-289

[8] Dach J., Pulka J., Janczak D., Lewicki A., Pochwatka P., Oniszczuk T. Energeticassessment of biogas plant projects based on biowaste and maize silage usage. Presented at: 6th International Conference on Environment and Renewable Energy; Hanoi, Vietnam; 2020 September 28-30

[9] Dalkılıc K, Ugurlu A. Biogas production from chicken manure at different organic loading rates in a mesophilic-thermopilic two-stage anaerobic system. Journal of Bioscience and Bioengineering.2015;120(3). 315-322

[10] Dalkılıç K,Ugurlu A. Influence of hydraulic retention time and reactor configuration during fermentation of diluted chicken manure. Applied Biochemistry and Biotechnology 2017;181(1). 157-176

[11] Deutsches Institut für Normung e. V. (DIN). DIN 38414 - 8: 1985-06 Deutsche einheitsverfahren zur wasser-, abwasser- und schlammuntersuchung; schlamm und sedimente (Gruppe S); Bestimmung des Faulverhaltens (S 8). Verfahren: Letzte Erg. 1985.

[12] Djeukoua B Energy valuation of animal excrement in the production of biogas: Study of the biomethanation of rabbit dungs in laboratory in Senegal. Petroleum and Chemical Industry International. Joint Event on 13th International Congress on Biofuels \& Bioenergy and Biofuels \& Bioeconomy October 18-20, 2018. Ottawa, Canada

[13] DornelasKC, Schneider RM,do AmaralAG.Biogas from poultry waste - Production and energy potential Environmental Monitoring and Assessment. 2017;189.407-408

[14] Fachagentur Nachwachsende Rohstoffe e. V. (FNR). Leitfaden Biogas. Von der Gewinnung zur Nutzung. Rostock: Druckerei Weidner; 2013.

[15] Rao AG, Prakash SS, Joseph J, Reddy AR, Sarma PN. Multi-stage high rate biomethanation of poultry litter with self-mixed anaerobic digester.Bioresource Technology. 2011;102(2). 729-735

[16] Helfrich D,Oechsner H. Hohenheimer Biogasertragstest. Vergleich verschiedener Laborverfahren zur Vergärung von Biomasse. Agrartechnische Forschung. 2003;9(3):27-30. 
[17] Herrmann C, Idler C, Heiermann M. Improving aerobic stability and biogas production of maize silage using silage additives. Bioresource Technology. 2015;197. 393-403

[18] Hutnan M. Maize silage as substrate for biogas production. Advances in Silage Production and Utilization.London:IntechOpenLimited; 2016.

[19] Hutnan M., Špalková V., Bodík I., Kolesarova N., Lazor M. Biogas Production from Maize Grains and Maize Silage. Polish Journal of Environmental Studies. 2010;19(2). 323-329

[20] Institut für Energetik und Umwelt $\mathrm{GmbH}$, Bundesforschungsanstalt für Landwirtschaft, Kuratorium für Technik und Bauwesen in der Landwirtschaft e.V. Handreichung. Biogasgewinnung und -nutzung. Gülzow: Fachagentur Nachwachsende Rohstoffe e. V. (FNR); 2006.

[21] Li Y., Achinas S., Zhao J., Geurkink B., Krooneman J., Euverink G. Co-digestion of cow and sheep manure: Performance evaluation and relative microbial activity. Renewable Energy. 2020;153 41-45

[22] Mahadevaswamy M, Venkataraman LV. Integrated utilization of rabbit droppings for biogas and fish production. Biological Wastes. 1988;25(4) 656-662

[23] Marchioro V., Steinmetz R., Amaral A., Gaspareto T., Treichel H., Kunz A. Poultry litter solid state anaerobic digestion: Effect of digestate recirculation intervals and substrate/inoculum ratios on process efficiency. Agroecology and Sustainable Food Systems 2018;2(46) 1-10

[24] Miah M., Rahman A K M, Akanda M., Pulak A., Rouf Md. Production of biogas from poultry litter mixed with the co-substrate cow dung. Journal of Taibah University for Science. 2016;10(4) 497-504

[25] Mönch-Tegeder M, Lemmer A, Oechsner H, Jungbluth Investigation of the methane potential of horse manure. Agricultural Engineering International: CIGR Journal.. 2013;15(2). 161-172

[26] Mukumba P,Makaka G,Mamphweli S. Biogasification of horse dung using a cylindrical surface batch biodigester. Frontiers in Bioenergy and Biofuels. London: IntechOpen Limited; 2017.

[27] Nagy, Gábor \& Takács, Alexandra \& Kállay, András \& Mentes, Dóra. The anaerobic digestion of sheep manure in self-designed low-cost biogas reactor.AnalectaTechnicaSzegedinensia. 2018;12(2). 13-23

[28] Nagy G, Takács A, Kállay AA. (2019). The energy aspects of biogas production from sheep manure. Presented at: $9^{\text {th }}$ European Combustion Meeting 2019; Lisbon, Portugal; 2019.14-17 April 
[29] Peiretti, Pier Giorgio \& Tassone, Sonia \& Gai, Francesco \& Gasco, Laura \& Masoero, Giorgio. Rabbit feces as feed for ruminants and as an energy source. Animals. 2014;4(4).755-766

[30] PfeifferD, Dittrich-Zechendorf M. Messmethodensammlung Biogas: Methoden zur Bestimmung von analytischen und prozessbeschreibenden Parametern im Biogasbereich. Leipzig: Deutsches Biomasseforschungszentrum gemeinnützige GmbH (DBFZ); 2012.

[31] A. Smurzynska, J. Dach, K. Kozlowski etal. Relevant biogas substrate - Maize silage vs slaughterhouse waste. Presented at: $8^{\text {th }}$ International Conference on Information and Communication Technologies in Agriculture, Food and Environment (HAICTA 2017); Cania, Greece; 2017 September. 21

[32] Lopes, MSP. Evaluation of biogas production from horse manure and assessment of biogas pathways in Portugal [Masters Dissertation, TécnicoLisboa]. Lisbon. Technical University of Lisbon. 2017

[33] Sun, Chen \& Cao, Weixing \& Banks, Charles \& Heaven, Sonia \& Liu, Ronghou. Biogas production from undiluted chicken manure and maize silage: A study of ammonia inhibition in high solids anaerobic digestion. Bioresource Technology. 2016;218. 1-7

[34] Teniza O, Solís M,Chicatto V.Methane production by co-digestion of rabbit waste with animal manure mixture. Presented at:XVII Congreso Nacional de Biotecnología y Bioingeniería; Cancún, México; 2013 June 23-26.

[35] VDI-Fachbereich Energietechnik. VDI 4630: Vergärung organischer Stoffe; Substratcharakterisierung, Probenahme, Stoffdatenerhebung, Gärversuche. Berlin: BeuthVerlag GmbH; 2006.

\section{Information about authors}

Miroshnichenko Irina V. - PhD in biological sciences, associate professor, department of technology of production and processing of agricultural products, Belgorod State Agricultural University named after V. Gorin, ul. Vavilova, 1, 308503, Mayskiy, Belgorod region, Russia, tel. +7 903887 3490, e-mail: imiroshnichenko_@mail.ru

Nikulina, Nadiia V. - scientific assistant, State Institute of Agricultural Engineering and Bioenergy, University of Hohenheim. Garbenstr. 9, 70599 Stuttgart, Germany.email: nadiia.nikulina@uni-hohenheim.de 